\title{
Case of paraspinal collection due to Burkholderia pseudomallei
}

\author{
Gayane Melikyan, ${ }^{1}$ Mohamed Badawi, ${ }^{2}$ Naveed Akhtar, ${ }^{1}$ Ahmed Hassan Elsetouhy ${ }^{3}$
}

'Department of Neurology/ Medicine, Hamad Medical Corporation, Doha, Qatar ${ }^{2}$ Department of Internal Medicine, Hamad Medical Corporation, Doha, Qatar ${ }^{3}$ Department of Radiology, Hamad Medical Corporation, Doha, Qatar

Correspondence to Dr Mohamed Badawi, mnbadawi@hotmail.com
To cite: Melikyan $\mathrm{G}$ Badawi M, Akhtar N, et al. BMJ Case Rep Published online: [please include Day Month Year] doi:10.1136/ bcr-2013-201447

\section{DESCRIPTION \\ Introduction}

Melioidosis is an infection caused by the facultative intracellular Gram-negative bacterium, Burkholderia pseudomallei. ${ }^{12}$ The most common clinical manifestations are pneumonia and localised skin infection. Encephalomyelitis can be observed approximately in $4 \%$ of cases.

\section{Case report}

This is a case of a 51-year-old Indian fisherman with a known case of DM TII and chronic hepatitis $B$ infection, who presented with fever and generalised body pain for 10 days followed by spastic paraplegia. The patient was diagnosed with sepsis based on blood analyses, and treated with meropenem. A lumber puncture showed normal cell count and glucose, but elevated proteins $(5.12 \mathrm{mg} / \mathrm{dL})$. MRI of the thoracic spine showed evidence of a localised collection over the right side with the largest pocket measuring around $1.5 \times 0.7 \mathrm{~cm}$ and involving the posterior paravertebral region of the fourth spinal muscles enhancing with contrast, with suspicion of intraspinal canal extension (figure 1). Histopathology from a CT-guided biopsy grew B pseudomallei. A blood culture grew only $B$ pseudomallei, while other cultures and PCRs for $\mathrm{TB}$ and viral panel were negative in blood and CSF. After 6 weeks of treatment with meropenem patient improved and was able to walk with walker.

\section{CONCLUSION}

Septicaemic melioidosis is associated with a very high mortality of about $90 \% .{ }^{2}$ Luckily, the outcome through to the seventh thoracic vertebrae, para-

in our patient was good despite the early deterioration with multisystem involvement and development of spastic paraplegia. This was probably related to the use of appropriate antibiotics. Antibiotics are given initially parenterally for 2 weeks, followed by oral treatment for 6 months.

\section{Learning points}

- Melioidosis is endemic in southeast Asia and northern Australia but some cases could be imported in non-endemic areas.

- Neurological complications (encephalomyelitis) can be observed in $4 \%$ of cases.

- The diagnosis of paraspinal collection or abscess associated with melioidosis should be discussed in febrile immunocompromised patients of $>40$ years of age who return from endemic areas with fever, sepsis and paraplegia.

\section{Competing interests None.}

Patient consent Obtained.

Provenance and peer review Not commissioned; externally peer reviewed.

\section{REFERENCES}

1 White NJ. Melioidosis. Lancet 2003;361:1715.

2 Cheng AC, Currie BJ. Melioidosis: epidemiology, pathophysiology and management. Clin Microbiol Rev 2005;18:383.
A

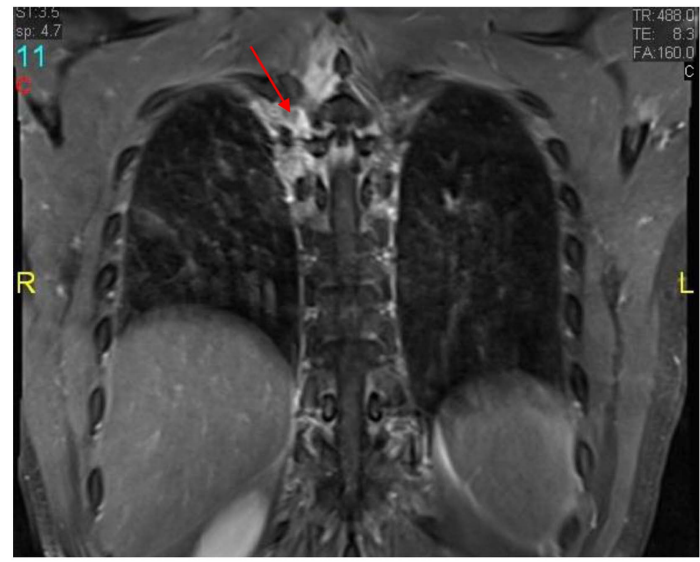

B

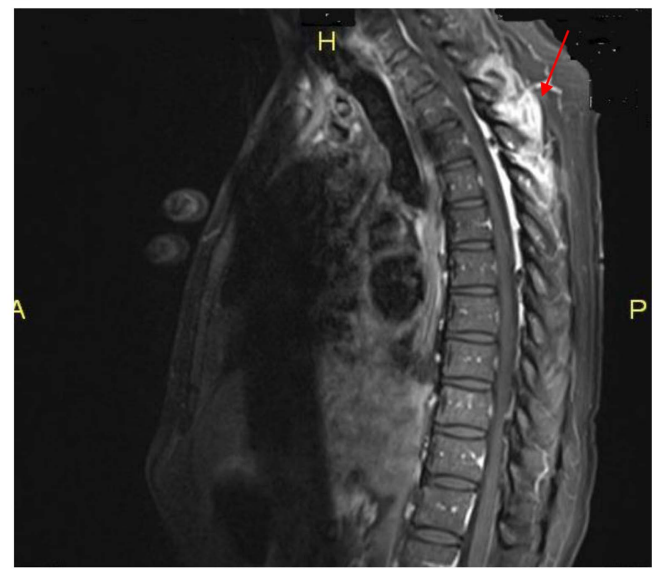

Figure 1 (A) Coronal T1 with contrast. (B) Sagital T1 with contrast. MRI of the thoracic spine showed evidence of a loculated collection over the right side with the largest pocket measuring around $1.5 \times 0.7 \mathrm{~cm}$ involving the posterior paravertebral region of the fourth through the seventh thoracic vertebrae, paraspinal muscles. 
Copyright 2013 BMJ Publishing Group. All rights reserved. For permission to reuse any of this content visit http://group.bmj.com/group/rights-licensing/permissions.

BMJ Case Report Fellows may re-use this article for personal use and teaching without any further permission.

Become a Fellow of BMJ Case Reports today and you can:

- Submit as many cases as you like

- Enjoy fast sympathetic peer review and rapid publication of accepted articles

- Access all the published articles

- Re-use any of the published material for personal use and teaching without further permission

For information on Institutional Fellowships contact consortiasales@bmjgroup.com

Visit casereports.bmj.com for more articles like this and to become a Fellow 